\title{
The Rali affair: A case study for a free press
}

In early 1996, a PNG news media cover-up was alleged over the socalled Topul Rali affair. An exposé by the student newspaper Uni Tavur led to a clash with the University of PNG administration and the journalism programme was closed down three years later.

\section{By DAVID ROBIE}

PUBLICITY is one of the most powerful avenues of opposing suppression of intellectual dissent. Suppression usually takes the form of blocking publications of free speech, or of victimising those who hold the dissenting views, such as by harassment, smear campaigns and sackings. Publicity is an immediate challenge to suppression in two ways. First, it exposes or threatens to expose the suppressed views themselves. Second, it threatens to mobilise opposition to the practices, policies or power of the groups instituting the suppression.

- Brian Martin and Clyde Manwell, Intellectual Suppression: Australian Case Histories, Analyses and Responses, Sydney: Angus and Robertson, 1986, p 253.

\section{Summary of the case:}

IN DECEMBER 1995, one of the University of Papua New Guinea's most prominent academics, Dr Topul Rali, at that time acting Dean of Science, was implicated in a protest against the Administration Office of the university over the murder of an anthropology lecturer on campus. Dr Rali is well known in some Australian and international academic circles. The dead woman, Janet Kisau, was the second lecturer to be murdered at the university in less than seven months. In addition, two students were murdered during 1995. The protesters caused an estimated K10,000 worth of damage during the raid and a senior 114 PACIFIC JOURNALISM REVIEW 5:1 1999 
administration staff member was injured.

The affair was hushed up by the administration, but the incoming ViceChancellor, Dr Rodney Hills, instituted an inquiry into the raid in February 1996. In March, the University Council voted in an extraordinary meeting to dismiss Dr Rali from his position. No public statement was ever issued by the administration about the affair and the council meeting was conducted in secrecy.

Uni Tavur, the training newspaper published by the journalism programme at UPNG, gathered information about the affair and published reports. These included a full-page background article and a front-page story about the sacking of Dr Rali. (Uni Tavur, 1996a, 1996b, 1996c) The university administration pressured the paper over the stories but avoided doing so in public. News reports from the newspaper about the affair to Pacnews were secretly removed from the university administration facsimile room and destroyed. The lecturer in charge of the newspaper (along with two senior faculty staff members) were summoned to the Vice-Chancellor's office and the newspaper accused of "breach of confidence" and "defamation" and a campaign of vilifying the newspaper was conducted in some academic quarters. A demand was made to reveal the newspaper's sources who had leaked information from the University Council. However, the public response to the publication of the stories was overwhelmingly favourable.

In the next issue, Uni Tavur published an editorial exposing the pressure on the paper and defending its editorial decision to publish the stories in the public interest. Nothing further was said about the affair by the administration.

\section{Background:}

21 December 1995: An anthropology lecturer, Janet Kisau (quite well known in Australia), was murdered in strange circumstances in the housing compound at the University of Papua New Guinea. She was said to be with "off-duty police officers" at the time she was shot dead outside her home. She was the second academic to be murdered at the university in less than seven months. Two students were also murdered in 1995 (one by soldiers on campus). All murders were related, but none were fully investigated and nobody was charged in any of the cases. (Uni Tavur, 1996c)

22 December 1995: Dr Topul Rali, head of the Chemistry Department (and at that time acting Dean of the Science Faculty), and two other people were involved in an alleged raid on the Administration Office at the university in 
DAVID ROBIE

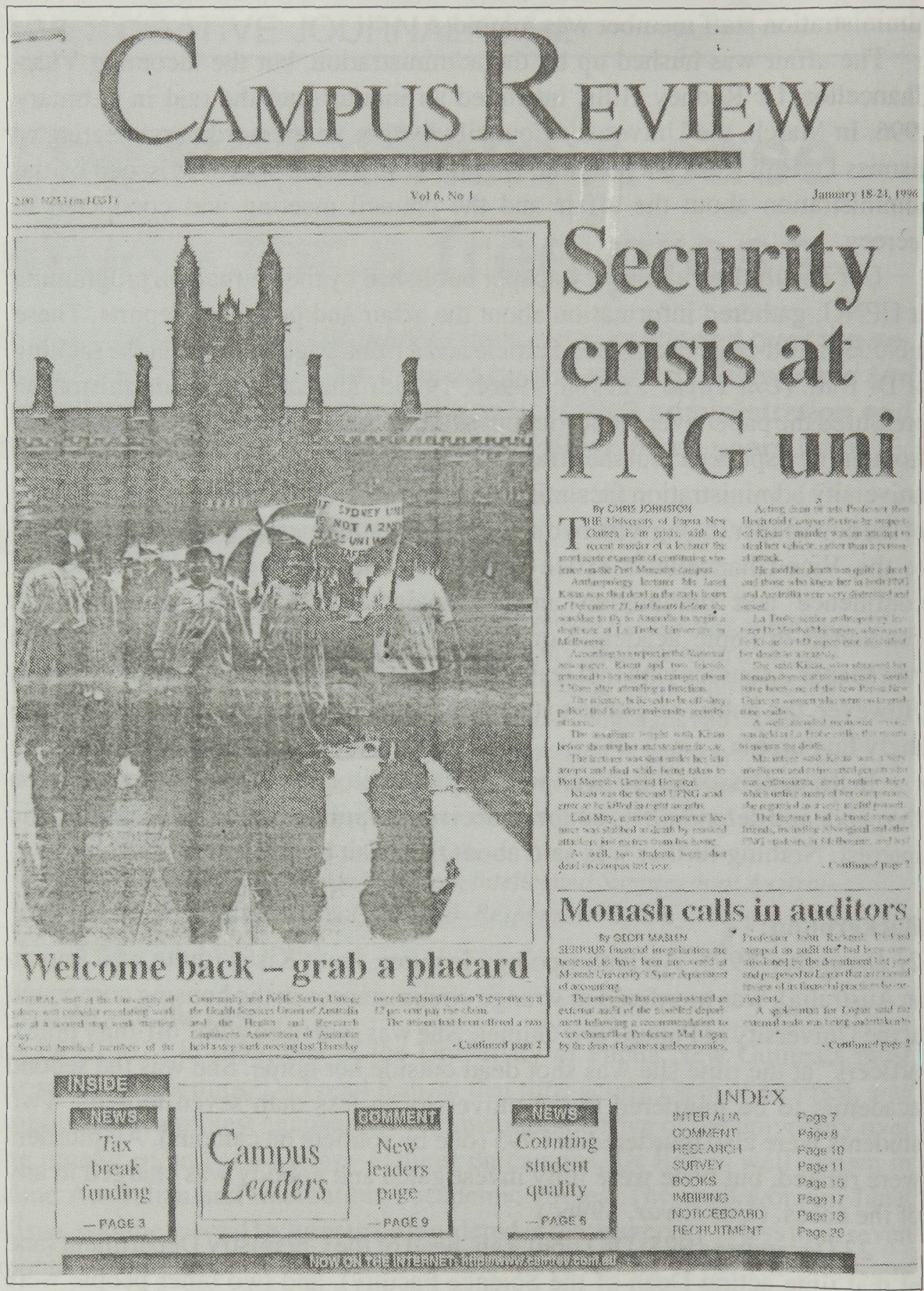

An Australian Campus Review of the UPNG crime wave, 18 January 1996. 116 PACIFIC JOURNALISM REVIEW 5:1 1999 
protest over Ms Kisau's murder. During the incident, a computer was trashed and the Acting Bursar received a gash on the leg.

Dr Rali was regarded as one of the brightest national PNG academics and was sometimes touted as a potential future vice-chancellor. He also had a reputation in some quarters for drinking and harassment of some individuals at the university. He had been chairperson of the university's disciplinary committee which adjudicates on alleged offences by students. The university had suffered from a law and order problem for some years, including the murder of four students in three years.

February 1996: The incoming Vice-Chancellor, Dr Rodney Hills (from Australia), who replaced Joseph Sukwianomb (a PNG national who had been ousted by the University Council the previous year for alleged mismanagement), set up an inquiry into the Rali affair. For weeks it had been a hot topic of debate around the campus, but no reports were carried in the local daily papers, or weekly press.

14 February 1996: An anonymous letter (apparently written by an UPNG academic) was published by The National, one of the PNG's two daily newspapers, alleging a news media cover-up of the Rali affair (The National, 1996). It said in part:

The UPNG community was so terrified that it shut down for the day, and many women did not return to work the next day.

Later that afternoon, the drunken 'academic' threatened the lives of the head of the Extension Studies department and his wife, causing them to leave Papua New Guinea and the US Embassy put out a warning about the danger of visiting PNG.

The name of the man who perpetrated these crimes and blighted the name of PNG is known to all at UPNG, but it has been kept secret by the media (campus reporters are said to be his drinking mates).

The man has a record of violence and intimidation on campus.

23 February 1996: Uni Tavur published a front page report about the inquiry under the headline ACADEMIC SUSPENDED OVER OFFICE RAID. The Vice-Chancellor was unhappy with publication of the story, although he never conveyed this directly to the paper. Also, he was cited in the story about being non-committal over the inquiry while the Deputy Vice-Chancellor, Professor Lance Hill was quoted by the newspaper as confirming Dr Rali had been suspended pending the investigation. (Uni Tavur, 1996a).

Uni Tavur has a 2000 circulation with about half distributed on campus and 
the balance available through Port Moresby news agencies and mailed out to subscribers throughout the Pacific. The role of lecturer in journalism (in charge of all print projects) is to supervise the newspaper as managing editor, and also to educate/train the journalism students. A student editor is appointed each semester. In 1995, the paper was revamped as a professional tabloid, printing with the Post-Courier daily. Previously it had been an A4 format since it began publishing in 1974. It also has a Web edition: http://www.journ.upng.ac.pg/

Uni Tavur has traditionally been independent from the university administration with vigorous and outspoken editorials and barbed cartoons. Its role is quite different from the modest official weekly university newsletter, The University This Week. The university Students Representative Council does not have its own publication and at times has unsuccessfully tried to influence the editorial policy of Uni Tavur. But the paper has resisted any attempt to undermine its independence by either the administration, or the SRC. It covers both national issues and campus news. It also has an editorial charter.

The 23 February 1996 issue contained a full-page background article about the murder of Janet Kisau and the crime problems on the campus. The Uni Tavur reporters had great difficulty trying to speak to Dr Rali to get his side. After the paper appeared, the reporters were threatened. Efforts to get a follow-up story with Dr Rali's comments were in vain.

21 March 1996: The newspaper received information in its editorial office that the University Council was meeting that morning in an extraordinary session to decide the fate of Dr Rali after the inquiry. A senior reporter (in his 40 s, who had returned to university to gain a bachelor's degree to upgrade his earlier Diploma in Media Studies) was assigned to cover the story. He had excellent sources within the council. Within half an hour after the meeting, two councillors had leaked the information to the reporter that the council had voted to dismiss Dr Rali.

The newspaper was due to go to press that evening and the following issue was due out a month later (because it did not publish during the mid-semester breaks). The reporter had already written the story and it was independently verified by the lecturer that what was written was true.

The dilemma for the editorial staff was whether the paper should run with the story when clearly Dr Rali would probably not have been formally told of the decision by the time the paper came out next morning. It was decided that the issue was so overwhelmingly in the public interest that it must be published.

The student reporter who was chief-of-staff was asked to phone the Vice118 PACIFIC JOURNALISM REVIEW 5:1 1999 
Chancellor to ask for comment in view of the story being run. He made no comment for publication but harangued the reporter about the identity of the sources of information. He also said it was a "private disciplinary matter".

22 March 1996: The report appeared on the front page of Uni Tavur under the headline COUNCIL VOTES TO SACK RALI. (Uni Tavur, 1996c)

The mood at the university was strongly in favour of the publication and relief that action had finally been taken by the administration to help restore security on campus. However, the administration issued no public statement even to the daily news media. Instead, it was apparent that the Vice-Chancellor was angry at the publication (although once again it was never conveyed to the journalism programme directly, always through other academics). It was clear the university was doing its best to keep the affair out of the public arena.

29 March 29 1996: Several days later it was discovered that a fax message from Uni Tavur to Pacnews cooperative in Vanuatu with a photocopy of the front page (and to two other destinations, in the Solomon Islands and Radio NZ International) had been censored by a senior member of the Registrar's Office. She removed the messages from the university fax room without any reference to the lecturer in charge or editors and interfered with a long-standing arrangement the newspaper had to fax its front page to those outlets.

A formal letter of complaint over the censorship was written to the ViceChancellor. In response, the dean of the Arts Faculty, the head of the South Pacific Centre for Communication and Information in Development (which included the journalism programme) and the lecturer were summoned to the VC's office. The lecturer was given an angry dressing down over alleged unprofessionalism, breach of confidence, unethical behaviour of reporters and defamation. No opportunity was given to defend the newspaper's professional conduct. The Vice-Chancellor wanted to know the identity of the paper's sources on the University Council. This information was refused and the ViceChancellor was reminded it was a breach of journalistic ethics to reveal confidential sources. (In fact, one of the sources was a senior administrator but his future could well have been on the line.)

The Vice-Chancellor then threatened to summon the lecturer (and/or the reporter) before the University Council in an attempt to force revelation of the sources. The VC was given copies of the PNG Journalist's Association Code of Ethics, the International Federation of Journalists Code of Ethics and a copy of the newspaper's own charter of editorial independence. The lecturer also declared that he was satisfied with the performance of the reporters and he would 


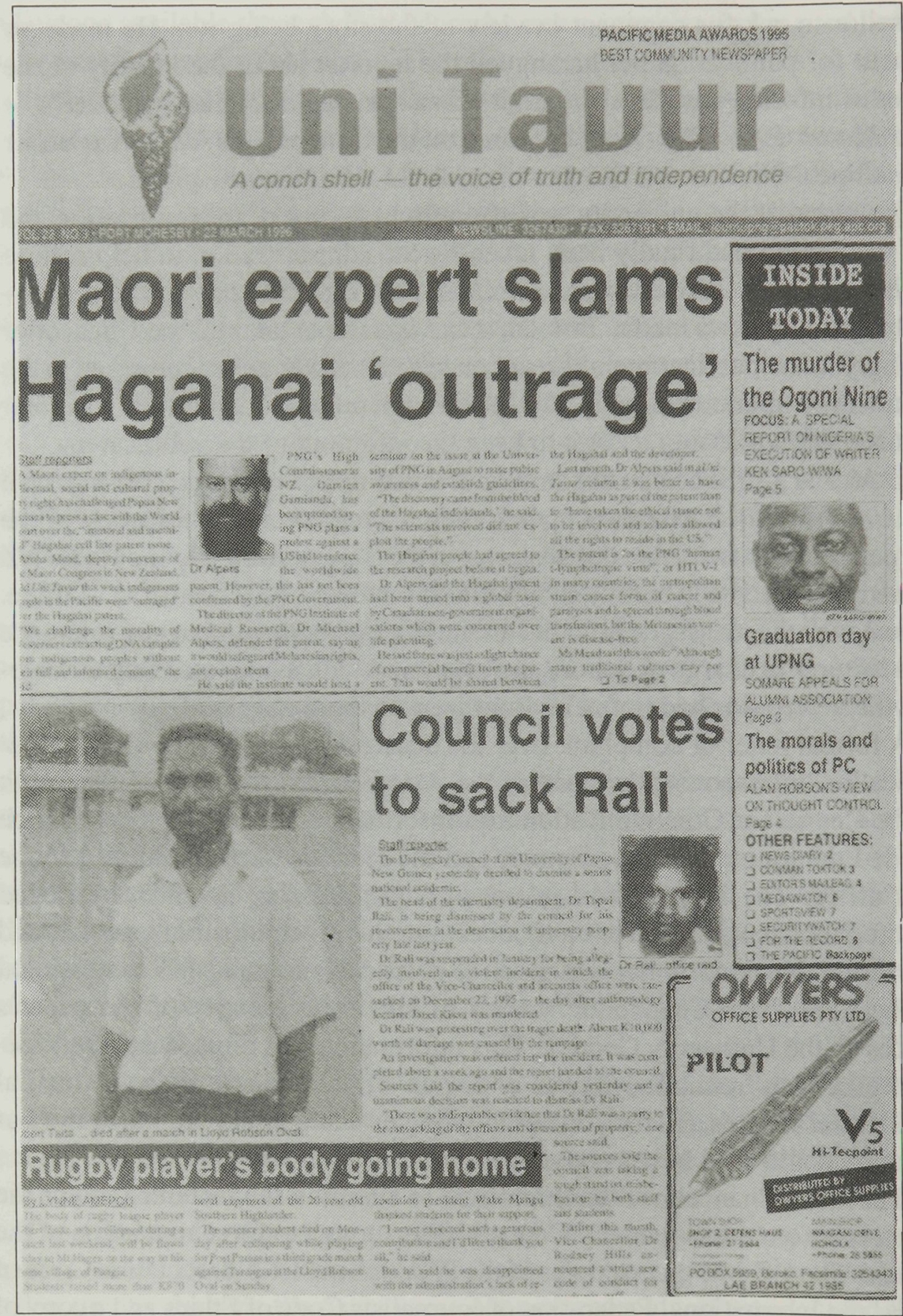

Uni Tavur's report of the sacking of Dr Rali, 22 March 1996. 
defend their efforts and their ethics.

News of this encounter spread quickly around the campus and several senior academics indicated that the newspaper should strive to maintain its editorial independence because apart from the issues of freedom of the press, the future of academic freedom at the University of PNG could also be under threat.

26 April 1996: Uni Tavur published an editorial under the headline A FREE STUDENT PRESS AND ITS RESPONSIBILITY defending the decision to publish the Rali story and revealing that the paper was under pressure from the administration over publication. (Uni Tavur, 1996d)

In the same issue, a front page article was published announcing that Uni Tavur had won the Journalism Education Association's Ossie Award for Student Publication of the Year Award (best regular paper in Australia, NZ and the Pacific journalism schools).

19 July1996: Unemployed and facing charges of illegal possession of firearms and pornographic materials - charges which he denied, Dr Rali commented on the implications of his case for higher education in PNG, saying: "I have always been frontal (sic) in nationalist issues and I happen to be a victim of bad publicity and reversal of the University of PNG staff development programme." He said he wanted to speak out because of reports in Australia's Campus Review "implying that I am a criminal, so my academic and intellectual friends throughout Australia, New Zealand, Europe and the United States will know the full details". (Rali, 1996)

\section{Analysis:}

After the edition of Uni Tavur with an editorial declaring "such a major incident should not be masked by secrecy ... the public has the right to know" was published, the university administration was reluctant to speak to reporters. (Uni Tavur, 1996d)

The issues involved in this affair are important, particularly as they coincided with a major debate on freedom of information and the news media in PNG. The Government of then Prime Minister Julius Chan sought to bring in legislation to curb the national media. Uni Tavur was the only independent newspaper outside the two national dailies, two national weeklies and the provincial fortnighly Eastern Star. Its continuing freedom is essential for diversity and plurality of the news media in the country.

Some might find it tempting to make comparisons with issues confronting 


\section{DAVID ROBIE}

the student press in Victoria, Australia, in 1996, such as the abolition of the student fees for political purposes to muzzle the student press and attempts to suppress Rabelais, the La Trobe University student magazine. (Messina, 1996) Rabelais appealed against a chief censor's decision that it be banned for publishing a guide in 1995 on how to shoplift and police were considering prosecuting it for publishing a photograph of Premier Jeff Kenneth's face framed in the cross hairs of a gun sight. However, such comparisons would be wrong. There are crucial differences. While the Victorian student papers were published by student bodies and staffed by few people with journalism education or training, Uni Tavur is published by a journalism programme and staffed by students who are educated in media ethics and techniques and aspire to be professional journalists.

\section{The issues involved:}

Freedom of the press and the right for the university and the wider public to be informed on an issue involving a senior academic with a high national and international profile.

Academic freedom in the sense that the staff of the university should be free to conduct the journalism education and training in a manner that is in keeping with professional standards, and independent from editorial interference by the university administration.

Uni Tavur and journalism education upholds the Papua New Guinea Journalists Association and International Federation of Journalists codes of ethics. It also has its own principled Editorial Charter:

1. To provide a vehicle for members of the University of Papua New Guinea community to communicate news and opinions to one another.

2. To inform the people of the nation about issues affecting Papua New Guinea (PNG).

3. To promote a fairer more tolerant society and to seek an improved quality of life for citizens of PNG.

4. To ensure that the activities and the concerns of the poor and powerless are represented.

5. To inform the nation of important media and information developments, and to contribute to the debate of ethical and media issues.

6. To offer practical advice to students about community and academic life.

Universities have a potential for ideological unmasking of the present order 


\section{Suppression is}

\section{essentially a}

back-up mechanism, who are not induced

or seduced by

privilege and status

to support the

powers that be by

keeping to their

\section{narrow activities}

\section{and staying out of political struggles.}

to keep those in line

which makes them periodically hotbeds of dissent. And this leads to attempts by elite groups to muzzle dissenting groups - particularly any university publication that is independent of the establishment. (Martin, 1986)

The University of PNG is modelled on Australian academic institutions. Australia's academe has many documented cases that support the argument for dissent - for example, Raymond Hoser, a whistleblower who exposed corruption in government bodies and the police in Victoria and is the author of the Hoser Files. David Rindos was an academic at the University of Western Australia who was denied tenure after exposing problems in the Archaeology Department.

According to Dr Brian Martin, of Whistleblowers Australia, academic institutions are protected in two ways: first by their own service in the maintenance of society, and second by the intellectual tradition of liberal education and freedom of opinion. Although this tradition, says Martin, often masks the reality of intellectual service to vested interests, it is also useful for defending dissent.

Suppression is essentially a back-up mechanism, to keep those in line who are not induced or seduced by privilege and status to support the powers that be by keeping to their narrow activities and staying out of political struggles on behalf of oppressed groups. Suppression is important precisely because dissidence is so infrequent. When the consensus of expert intellectual opinion is virtually unanimous, a single dissenting voice can make a big difference in helping to legitimise contrary views. (Martin, 1984)

Robert Pullan, founding president of the Free Speech Committee, says all fights about censorship are fights about power:"At some level we know instinctively that censorship is disreputable. Often, as we will see it, the censor disguises itself simply by denying that what it is doing is censorship. At the same time, the censor says it strongly favours free speech and adds a daunting PACIFIC JOURNALISM REVIEW 5:1 $1998 \mathbf{1 2 3}$ 


\section{DAVID ROBIE}

reminder of the power of words." (Pullan, 1994)

By publishing information about the Dr Rali affair, the newspaper Uni Tavur defied suppression and brought a hushed up affair into the public arena, exposing a double standard on ethical behaviour in Papua New Guinea's leading national university. And by making public the pressure on it from the administration, the paper thwarted attempts to muzzle its freedom to report and interpret on behalf of the public.

\section{References:}

DeMaria, William (1995), "Whistleblowers and Secrecy: Ethical emissaries from the public sector," paper presented to the Freedom of the Press Conference, Bond University, November 11.

Martin, Brian (1993), "Stamping out dissent", Newsweek, April 26, pp49-50.

- (1993), "Whistleblowers and why academic freedom is most threatened from within", Campus Review (Sydney).November 11-17, p 9.

- et al (1986), Intellectual Suppression: Australian Case Histories, Analysis and Response, Sydney: Angus and Robertson.

Messina, Alex (1996), education reporter, The Age, October 1, p1.

Pullan, Robert (1994), Guilty Secrets: Free Speech and Defamation in Australia, Sydney: Pascal Press.

Rali, Dr Topul (1996), "Sacked PNG academic speaks", Campus Review (Sydney), 5 June 1996, pp7-8 (this article includes Rali's analysis of the state of UPNG education and national PNG education policy); republished as "Ousted academic speaks" in Uni Tavur Toktok, July 19, pp5-6.

The National (1996), "News media cover-up alleged", republished in Uni Tavur, February 23.

Uni Tavur (1996a), Miise, Michael, "Academic suspended over office raid", February 23, p1.

- (1996b), Miise, Michael, "The tragedy of Janet Kisau”, February 23.

- (1996c), "Council votes to sack Rali", March 22, p1.

- (1996d), editorial, "A free student press and its responsibity", April 26, p4.

$\square$ David Robie formerly coordinated the journalism programme at the University of Papua New Guinea from 1993-97. He was editorial manager of Uni Tavur and revamped it as a professional tabloid in 1995, leading to it winning the Ossie Award for Best Student Publication. The publication of stories on the Rali affair led to conflict with the Australian Vice-Chancellor which culminated in the closure of the journalism programme in January 1999 as a "cost-cutting" exercise as part of the university's controversial restructing plan. 